\title{
Extraction of Catechins from Areca catechu L. Peel with different Solvent Type for Feed Additive of Broiler
}

\author{
Syintia Dwi Agustina ${ }^{1}$, Yose Rizal $^{2}$, Ardi $^{3}$, and Maria Endo Mahata ${ }^{2 *}$
}

\author{
${ }^{1}$ Magister Student at Graduate Program of Faculty of Animals Scienceat Universitas Andalas, Kampus Limau Manis, Padang, Indonesia, \\ 25163 \\ ${ }^{2}$ Lecturer at Under Graduate of Faculty of Animal Science, Universitas Andalas, and Graduate Program at Universitas Andalas, \\ KampusLimau Manis, Padang, Indonesia, 25163 \\ ${ }^{3}$ Lecturer at Under Graduate of Faculty of Agriculture Science, Universitas Andalas, and Graduate Program at Universitas Andalas, \\ Kampus Limau Manis, Padang, Indonesia, 25163 \\ 2*Corespondens Author : mariamahata@gmail.com / maria@ansci.unand.ac.id
}

\begin{abstract}
Catechins are secondary metabolites compound of flavonoids group that is naturally produced by plants and have health benefits as cholesterol-lowering, antioxidant, antimicrobial in mice.Rapid growth in broilers is often followed by high-fat growth as well, thus causing a high cholesterol content in the broiler's meat especially in thigh meatand wings.Feeding extract catechin in broiler as feed additive will reduce cholesterol or fat in broiler's meat. The catechins could be extracted by maceration method, so far there is no information about the type of solvent and extraction method for extraction of catechin from Areca catechu peel. The aims of this study to obtain the best combination of solvent type and maceration duration in extracting of catechins from betel nut peel. Areca catechu peel used in this study is a green-colored fruit peel, which washarvested from betel nut seeds in Batu Balang village, Lima Puluh Kota District, West Sumatra Province, Indonesia. This study was performed by using Factorial Experimental in Completely Randomized Design withtwo factors. The first factors was solvent types (water with an initial temperature at $80^{\circ} \mathrm{C}$, acetone distillate, and ethyl acetate distillate) and the second factors wasmaceration duration (6 hours, 12 hours, and 18 hours), each combination treatment was replicated 3 times.The variables observed were percentage of water content, percentage of yield, and percentage of total catechins. The results showed there was a significant interaction $(P<0.05)$ between type of solvent and maceration duration on yield percentage andtotal catechins percentage, while there was no interaction betweentype of solvent and maceration duration $(P>$ $0.05)$ on percentage ofwater content. Both type of solvent and maceration duration were significantly $(P<0.05)$ affectedyield percentage andtotal catechins percentage, whilepercentage ofwater content did not affect. It concluded the combination of distillate acetone solvent and maceration duration for 6 hours was the best combination to obtain catechin extract from Areca catechu peel. In this condition the percentage of water content was 10.53\%, yield percentage was $7.13 \%$, and percentage of catechin extract was $25.53 \%$.
\end{abstract}

Keywords-Areca catechu L. peel, catechin extract, feed additive, maceration duration, solvent type.

\section{INTRODUCTION}

Areca catechu L. is classified as a monocot plant of the Palmae family which is spread almost in all regions in Indonesia. According to the Central Statistics Agency (2017), Areca nut fruit production in Indonesia reached 314.51 tons with an area of 143,927 hectares. Areca nut seed is one of the potential non-oil export commodities in the international market. In 2016 the export volume of betel nuts reached 219,127 tons with a value of US \$ 277.78 million or around Rp. 3.9 billion(Yudha, 2017).

Areca nut fruits are exported in the form of seeds, so that after harvesting the Areca nut seeds will leave the fruit peel which is a waste and has not been widely used. Areca nut peel waste reaches $76 \%$ of the weight of fresh Areca nuts fruits (Mahata et al., 2018).Areca nut peel contains $65.41 \%$ water, $34.59 \%$ dry matter, $2.22 \%$ protein, $0.15 \%$ fat, $47.02-53.96 \%$ crude fiber, $0.28 \% \mathrm{Ca}, 0.36 \% \mathrm{P}$, and energy metabolism $1116 \mathrm{kcal} / \mathrm{kg}$ and analysis of betel nut peel with van Soest method showed betel nut peel contains 59.07\% Neutral Detergen Fiber (NDF), 44.74\% Acid Detergen Fiber (ADF), 27.44\% cellulose, $14.32 \%$ hemicellulose, and 17, 30\% lignin (Mahata et al., 2018).Furthermore, Mahata et al.(2018) explained the peel of betel nuts contained phytochemical compounds such as 
catechins of $1.466 \%$, total polyphenols $1.693 \%$, total alkaloids $1.382 \%$, and contained fatty acids consisting of $1.83 \%$ myristate, palmitate $16.386 \%$, stearate $2.751 \%$, oleic $34.130 \%$, linoleic $2.918 \%$, and linolenic $0.171 \%$.

Catechins was a popular phytochemical compound in Areca catechu plant. Catechins is a metabolic secondary from tannin which produce by plant naturally (Gruenwaldet al., 2000). Previous research showed catechins are beneficial for health, as cholesterol-lowering, antioxidants, antimicrobials. Some researcher reported that there was a decrease in the activity of pancreatic cholesterol esterase (pCEase) in vitro in mice given areca seed extract supplements with a reduction in plasma cholesterol by $25 \%$, and did not change triglyceride concentrations (Park et al., 2002). Furthermore, Ikeda (2008) reported that giving catechins from green tea was able to lower total cholesterol levels in rat blood plasmabecause catechins were able to effectively inhibit the absorption of cholesterol in the intestine.Yunarto et al. (2015) also reported, ethyl acetate fraction of gambier leaf extract containing catechins could inhibit the action of HMG-CoA reductase in mevalonate synthesis of HMGCoA in cells, to reduce total cholesterol, triglycerides, LDL and not increase HDL in rat blood plasma.Raederstorff et al. (2003) also reported that the administration of epigallocatechin-gallate from green tea to a dose of $0.7 \mathrm{~g} / \mathrm{day} / \mathrm{kg}$ body wight $(\mathrm{BW})$ was able to reduce LDL and blood plasma of mice. Mechanism of LDL reduction by catechins is reduced by the production of apolipoprotein $\mathrm{B}$ which is the main constituent component of LDL and as a radar for LDL receptors in cells (Babu and Liu, 2008).

Broiler is chicken that has high productivity, as meat producer. Broilers have relatively short growth and meat production compared to other livestock.Broiler chicken meat is one of the sources of animal protein that is widely consumed by the community because it is relatively inexpensive, easy to obtain, and has soft fibrous meat so that it is favored by all ages. Muliani (2015) stated the rapid growth of broilers is often followed by high-fat growth as well, thus causing a high cholesterol content in the broiler's body especially in thigh meat and wings. Along with public awareness of health, cholesterol content becomes the public's consideration in consuming broiler meat.The alternative offered is the use of catechins form betel nut peel as additive feeds on broiler rations to lowering cholesterol and fat in broiler meat.

The use of catechins in Areca catechupeel as a feed additive for broiler rations is limited because of high crude fiber content andit still bound in plant cells, so that it is necessary to proces by extracting of catechin from Areca catechu peel.Extraction is the process of separating the material from the mixture using an appropriate solvent. The extraction method is divided into 2 ways, by cold proces namedmaceration method, and by heat proces named soxhlet extraction. Maceration is the simplest method of extraction by immersing the sample powder in a suitable solvent at room temperature.Soxhletation is a method of extraction carried out in a device called soxhlet with a polar solvent based on its boiling point. Catechin extraction can be done by the maceration method. The choice of the maceration method in this study because the catechin compound was susceptible to heat, so it was not good to use the soxhlet method (Damanik et al., 2014).This is supported by Cheong et al. (2005) that the concentration of catechin compounds decreased in the Soxhlet method compared with the maceration method.

The choice of solvent type is very important when the extractionprocess. The solvent in maceration extraction process must be in accordance with the material to be extracted, and the solvent must be able to separate quickly after shaking or maceration extraction (Mamonto et al., 2014). Catechins are not soluble in cold water but dissolve in hot water, in alcohol, ethyl acetate, and almost insoluble in chloroform, benzene, and ether (Hidayatullah, 2008). The most efficient solvent for extraction of catechins from green tea is in hot water with temperature at $80^{\circ} \mathrm{C}$ with maceration duration at 60 minutes and obtained catechin at range $64-97 \%$ (Uzunalic et al., 2006).According to Damanik et al. (2014) stated the best solvent for extracting catechins from gambier is ethyl acetate concentration $95 \%$ with temperature at $60^{\circ} \mathrm{C}$, and maceration timeat 6 hours with catechin extraced is 87.14\%. According to Satriadi (2011) tannin extract on Areca catechu seeds from Pelaihari area in South Kalimantan can be obtained from both water solventat temperature $80^{\circ} \mathrm{C}$ with 12 hour maceration duration and acetone solvent with maceration duration for 12 hour, and tannin extracted obtained from both of solvent was $17.97 \%$, and $19.04 \%$ respectively.

This study aims was to obtain the best treatment combination between the type of solvent and the best maceration time, to get the optimal catechin extract from the peel of betel nuts as a feed additive broiler ration for lowering broiler blood serum cholesterol.

\section{MATERIAL AND METHOD}

\subsection{Materials Research}

The materials used in this study are green betel nut peel collected from Nagari Batu Balang, Lima Puluh Kota District, West Sumatra Province, Indonesia. In addition, aquades, water solvents (with an initial temperature at 
$80^{\circ} \mathrm{C}$ ), acetone distillate, and ethyl acetate distillate. To measure the catechin content of areca nut peel extract, ethyl acetate pro analysis (pa) 99,5\% and catechin standard were used.

The tools used in this research to produce Areca catechu peel flour are oven, grinding machine (ADR MPJ 200), 10 mesh sieve (ABM brand). Areca catechu peel extraction tools used were Erlenmeyer $250 \mathrm{ml}$ volume tubes, aluminum foil, rotary evaporator brand (RV 10 digital V), stirring rods, analytical scales, Whatman 42 filter paper diameter $125 \mathrm{~mm}$, thermometer, incubator shaker (New Brunswick brand). Catechin levels were measured with a UV spectrophotometer, with quartz cuvette equipment, ultrasonic bath, analytical balance, blender, excavator, $50 \mathrm{~mm}$ measuring flask, watch glass, petri dish, oven, ordinary filter funnel, $2 \mathrm{ml}$ pipette, Erlenmeyer with a $100 \mathrm{~mm}$ sharpener, and qualitative filter paper No.42.

\subsection{Research Implementation}

This study was performed by using Factorial Experimental in Completely Randomized Design with two factors. The first factors was solvent types (water with an initial temperature at $80^{\circ} \mathrm{C}$, acetone distillate, and ethyl acetate distillate) and the second factors was maceration duration (6 hours, 12 hours, and 18 hours), each combination treatment was replicated three (3) times.

\subsubsection{Sample Preparation}

Areca catechu peel waschopped and dried using an oven at $60^{\circ} \mathrm{C}$ until the water content reaches $14 \%$. Then the dried Areca catechu peel is milled by using grinding machine, then sieved with 10 mesh size sieve. Areca catechu peel flour which has been obtained then used for the extraction of catechins by the maceration method with different solvents.

\subsubsection{Catechin extraction}

Catechinwas extracted from Areca catechu peel flour by maceration method using different solvent (water with an initial temperature of $80^{\circ} \mathrm{C}$, acetone distillate, ethyl acetate distillate) by Uzunalic et al.(2006) method.The maceration extraction of Areca catechu peel flour is carried out by weighing $20 \mathrm{~g}$ of Areca catechu peel flour, and placed into a $250 \mathrm{ml}$ Erlenmeyer, then add with $180 \mathrm{ml}$ of different solvent (water solvent with an initial temperature of $80^{\circ} \mathrm{C}$, acetone, and ethyl acetate) in different Erlenmeyer for each solvent. Furthermore, Erlenmeyer was wrap with aluminum foil to avoid direct sunlight (avoiding light-catalyzed reactions) and they were shaked at incubator shaker for 10 minutes at $60^{\circ} \mathrm{C}$, and stirred for all parts of Areca catechu peel flour particles wereevenly mixed with solvent, so that extraction can be carried out perfectly. After 10 minutes, the Erlenmeyer was removed from the shaker incubator and left at room temperature according to different maceration duration treatment $(6,12$, and 18 hours), then filtered by using Whatman paper filter number 42. The filtrate obtained was collected in a bottle and wrapped with aluminum foil, then put into a rotary evaporator to vaporize its solvent, so a dry extract of catechins is obtained from each solvent.

\subsection{Observed variables}

\subsubsection{Percentage of Water Content}

The measurement of water content was obtained based on the AOAC method (Association of Official Analytical Chemists, 1990).

\subsubsection{Percentage of Yield}

Extract yield was calculated by ratio of extracted weight produced with the weight of the extracted Areca catechu peel, as below:

$\%$ Yield $=$ Extract mass $(\mathrm{g}) /$ (Mass Simplicia (g) $\mathrm{x} 100 \%$

\subsubsection{Percentage of Total Catechin}

The analysis of the content of the catechin flour of Areca catechu peel is done by SNI method (Indonesian National Standard, 2000).

\section{RESULT AND DISCUSSION}

3.1. Effect of Solvent Type and Maceration Time on Percentage of Moisture Content of Crude Catechin Extract from Areca catechu $\mathbf{L}$.

The average percentage of the water content of crude catechin extract of Areca catechu L. peel in each treatment can be seen in Table 1 .

Table 1. Mean percentage (\%) of the water content of crude catechin extract of Areca catechu L. peel based on the solvent type and maceration time.

\begin{tabular}{|c|c|c|c|c|}
\hline \multirow[b]{2}{*}{ Type of Solvent } & \multicolumn{3}{|c|}{ Maceration Time } & \multirow[b]{2}{*}{$\begin{array}{c}\text { Averag } \\
\text { e }\end{array}$} \\
\hline & $\begin{array}{l}\text { M1 (6 } \\
\text { hours) }\end{array}$ & $\begin{array}{l}\text { M2 (12 } \\
\text { hours) }\end{array}$ & $\begin{array}{c}\text { M3 } \\
(18 \\
\text { hours) }\end{array}$ & \\
\hline $\begin{array}{l}\text { P1 (water with } \\
\text { an initial } \\
\text { temperature of } \\
80^{\circ} \mathrm{C} \text { ) }\end{array}$ & 10,95 & 10,91 & 10,85 & 10,90 \\
\hline $\begin{array}{l}\text { P2 (acetone } \\
\text { distillate) }\end{array}$ & 10,53 & 10,47 & 10,96 & 10,65 \\
\hline $\begin{array}{l}\text { P3 (ethyl acetate } \\
\text { distillate) }\end{array}$ & 9,93 & 10,17 & 10,93 & 10,35 \\
\hline Average & 10,47 & 10,52 & 10,91 & \\
\hline
\end{tabular}

Note: ns: not significantly different $(\mathrm{P}>0.05)$ SE: Standard error (0.019) 
Based on the results of an analysis of variance showed that there was no interaction $(\mathrm{P}>0.05)$ between the type of solvent (factor A) and maceration time (factor B) to the percentage of water content from crude catechin extract of Areca catechu L.Table 1 shows the percentage of the water content of crude catechin extract of Areca catechu L. peel is 9.93 to $10.96 \%$.

Extract water content is the weight of the extract after drying at a temperature of $105^{\circ} \mathrm{C}$ for 30 minutes or after obtaining a constant weight and expressed in percent (Ratnani et al., 2015). Determination of water content aims to provide a minimum limit or the range of the amount of water content in areca nut peel extract. There is no interaction between the type of solvent and the maceration time allegedly because there is no limitation of the time of evaporation of the solvent so that the solvent used at the time of extraction evaporates completely and produces a thick extract with almost the same water content. Prasetyo and Inoriah (2013) reported the process of drying or evaporation of solvents in an extract that is less than optimal can affect the high water content of the extract.This result is different from Damanik (2014) who reported that the highest water content of gambier leaf extract was found in water solvent which was $10.225 \%$ and the lowest water content was found in ethyl acetate $95 \%$ solvent which was equal to $0.225 \%$ with limitation of solvent evaporation time for 60 minutes. The high water content in water is due to the boiling point of the water solvent being higher than ethyl acetate. According to Susanti (2012) states that a solvent must have a boiling point low enough so that the solvent is easily evaporated without using high temperatures in the purification process, ethyl acetate is a type of solvent that has a relatively low boiling point of $77 \mathrm{oC}$ so that it is easily evaporated.

DepKes (2008) states that the water content standard of plant extracts in general is $<10 \%$, and the water content of catechin extracts from gambir is $<14 \%$. Zulharmita et al., (2012) stated the water content of traditional medicine preparations and extracts should not be more than $10 \%$. The water content of EKKBP obtained in this study has met the specified extract water content standard. EKKBP water content in this study ranged from 9.93 to $10.96 \%$, higher than the results of research Ozdemir et al. (2018) the water content of catechin extracts in black tea ranged from 4.78 to $5.45 \%$. Yunarto et al. (2015) reported the moisture content of the ethyl acetate fraction of gambir leaf extract was $2.23 \%$. However, lower than the results of research Ratnani et al (2015) states that the water content of the bitter leaf extract is $13 \%$ exceeds the allowed standard $(<10 \%)$, causing a high rate of microbial contamination of $3.1 \times 107 \mathrm{CFU} / \mathrm{g}$ with a standard that is no more than $104 \mathrm{CFU} / \mathrm{g}$. According to Yunarto et al. (2017) stated that good storage of catechin extracts $<10 \%$ because gambier plant catechin compounds are hygroscopic (can draw air water) causing microbial activity is unstable and easily oxidized. The same thing was also reported by Utami (2017) that moisture content exceeding $10 \%$ can cause the extract to be easily overgrown with microbes which will reduce the stability of the extract.

\subsection{Effect of Solvent Type and Maceration Time on Percentage of Total Yield of Crude Catechin Extract from Areca catechu $\mathrm{L}$.}

The average percentage of total yield of crude catechin extract of Areca catechu L. peel in each treatment can be seen in Table 2 .

Table 2. Average percentage (\%) yield of crude catechin extract of Areca catechu L. peel with different types of solvents and maceration times.

\begin{tabular}{|c|c|c|c|c|}
\hline \multirow[b]{2}{*}{ Type of Solvent } & \multicolumn{3}{|c|}{ Maceration Time } & \multirow[b]{2}{*}{$\begin{array}{c}\text { Averag } \\
\text { e }\end{array}$} \\
\hline & $\begin{array}{c}\text { M1 (6 } \\
\text { hours } \\
\text { ) }\end{array}$ & $\begin{array}{l}\text { M2 (12 } \\
\text { hours) }\end{array}$ & $\begin{array}{l}\text { M3 (18 } \\
\text { hours) }\end{array}$ & \\
\hline $\begin{array}{l}\text { P1 (water with } \\
\text { an initial } \\
\text { temperature of } \\
80^{\circ} \mathrm{C} \text { ) }\end{array}$ & $8,20^{\mathrm{a}}$ & $8,14^{\mathrm{a}}$ & $7,94^{\mathrm{b}}$ & $8,09^{a}$ \\
\hline $\begin{array}{l}\text { P2 (acetone } \\
\text { distillate) }\end{array}$ & $7,13^{c}$ & $6,91^{\mathrm{d}}$ & $6,78^{d}$ & $6,94^{b}$ \\
\hline $\begin{array}{l}\text { P3 (ethyl } \\
\text { acetate } \\
\text { distillate) }\end{array}$ & $1,44^{\mathrm{e}}$ & $1,38^{\mathrm{e}}$ & $1,37^{\mathrm{e}}$ & $1,40^{c}$ \\
\hline Average & $5,59^{a}$ & $5,48^{b}$ & $5,36^{c}$ & \\
\hline
\end{tabular}

Note: Superscripts with different letters show significantly different effect $(\mathrm{P}<0.05)$

Based on the results of the analysis of variance showed that there was an interaction that significantly different effect $(\mathrm{P}<0.05)$ between factor $\mathrm{A}$ (a type of solvent) and factor $\mathrm{B}$ (maceration time) to the percentage of the total yield of crude catechin extract of Areca catechu L. peel.

DMRT test results showed that the treatment of P1M1 (water solvent with an initial temperature of $80 \mathrm{oC}$ and maceration time 6 hours), and P1M2 (water solvent with an initial temperature of $80 \mathrm{oC}$ and maceration time 12 hours) gave a significant effect on the treatment other.

The yield of crude catechin extract of Areca catechu L. peel obtained in this study ranged from $1.37 \%$ to $8.20 \%$. The highest total yield of crude catechin extract of Areca catechu L. peel was obtained from the treatment of water with an initial temperature of $80^{\circ} \mathrm{C}$ with maceration 
periods of 6 and 12 hours with values of $8.20 \%$ and $8.14 \%$, respectively. The total yield of crude catechin extract of Areca catechu L. peel with the highest acetone solvent was obtained at 6 hours maceration time which was $7.13 \%$. While the lowest yield was found in the treatment of ethyl acetate solvents with different maceration times $(6,12$, and 18 hours), namely: $1.44 \%, 1.38 \%$, and $1.37 \%$.

The high yield of EKKBP in the treatment of P1M1, and P1M2 because catechin compounds found in the skin of betel nuts are polar and will dissolve with polar solvents. According to Sayuti (2017), the suitability of the nature of the solvent and the dissolved substance will affect the percentage of yield. Catechin compounds are polyphenol compounds (Yeni et al., 2017), polyphenol compounds are polar (Evans, 2000). According to Tiwari et al. (2011), water is a universal polar solvent, and acetone is also classified as a polar solvent, so the yield of EKKBP becomes high in the combination of treatments P1M1, P1M2, followed P1M3, and P2M1. Ethyl acetate is a semi-polar solvent, and is not suitable for dissolving polar catechin compounds, so the total yield of EKKBP is low in the treatment of P3M1, P3M2, and P3M3. Firdiyani et al. (2015) stated that ethyl acetate is a solvent with semipolar characteristics.

Types of solvents different in this study showed significant differences in the yield content of EKKBP. The yield content obtained from the water solvent with an initial temperature of $80 \mathrm{oC}(8.09 \%)$ higher than acetone $(6.94 \%)$ and ethyl acetate $(1.40 \%)$, and the yield of acetone is higher than ethyl acetate. The high yield of water solvents is due to its nature as a universal solvent and the level of polarity is higher than that of acetone so that more polar substances or compounds from areca nut peels can dissolve, and accumulate into more yields than acetone solvents and ethyl acetate. According to Burdick \& Jackson (2012) air is a polar solvent with a polarity index of 10.2 , acetone is a polar solvent with a polarity index of 5.1, while ethyl acetate is a semi-polar solvent with a polarity index value of 4.4.Ethyl acetate solvents are classified as semi-polar solvents so they are less able to dissolve polar substances or compounds.

In this study, the longer maceration time $(6,12$, and 18 hours) the reduced yield of EKKBP obtained for all types of solvents. The highest yield was obtained at 6 hours maceration $(5.59 \%)$, then the extension of maceration time was 12 hours, the yield was reduced at $5.48 \%$, and at 18 hours the yield was $5.36 \%$. The low yield due to prolongation of maceration is caused by the process of withdrawal and the amount of compounds from betel nut peel that can dissolve in each solvent has reached a maximum so that the extension time is not much more compounds left in the peel of betel nut. The results of this study differ from those reported by Kamaluddin (2014), that the longer the extraction time will increase the extract yield. According to Kristian et al. (2016) the longer the extraction time, the chance for the material to contact the solvent will be greater, so that the total yield obtained will be high up to the saturation point of the solution, but the number of certain compounds will decrease after reaching the optimal time.

\subsection{Effect of Solvent Type and Maceration Time on the Percentage of Total Catechins from Betel Nut Peel \\ The average percentage of total catechins from the} peel of betel nut in each treatment can be seen in Table 3 .

Table 3. Average percentage (\%) of catechins from the extraction of betel nut (Areca catechu L.) based on the type of solvent and maceration time

\begin{tabular}{lcccc}
\hline & \multicolumn{3}{c}{ Maceration Time } & \\
\cline { 2 - 3 } Type of Solvent & M1 (6 & M2 (12 & M3 (18 & Average \\
& hours & hours) & hours) & \\
\hline
\end{tabular}

\begin{tabular}{|c|c|c|c|c|}
\hline $\begin{array}{l}\text { P1 (water with } \\
\text { an initial } \\
\text { temperature of } \\
80^{\circ} \mathrm{C} \text { ) }\end{array}$ & $5,60^{c}$ & $4,65^{\mathrm{c}}$ & $4,46^{c}$ & $4,90^{b}$ \\
\hline $\begin{array}{l}\text { P2 (acetone } \\
\text { distillate) }\end{array}$ & $25,53^{\mathrm{a}}$ & $16,89^{b}$ & $17,17^{\mathrm{b}}$ & $19,87^{\mathrm{a}}$ \\
\hline $\begin{array}{l}\text { P3 (ethyl acetate } \\
\text { distillate) }\end{array}$ & $23,68^{\mathrm{a}}$ & $17,68^{\mathrm{b}}$ & $17,90^{\mathrm{b}}$ & $19,75^{\mathrm{a}}$ \\
\hline Average & $18,27^{\mathrm{a}}$ & $13,07^{b}$ & $13,18^{b}$ & \\
\hline
\end{tabular}

Note: Superscripts with different letters show significantly different effect $(\mathrm{P}<0.05)$

Based on the results of an analysis of variance showed that there was an interaction that gave a significantly different effect $(\mathrm{P}<0.05)$ between factor $\mathrm{A}$ ( $\mathrm{a}$ type of solvent) and factor $\mathrm{B}$ (maceration time) to the percentage of total EKKBP catechins.

DMRT test results showed that P2M1 treatment (acetone solvent and maceration time 6 hours) had a significantly different effect on other treatments.

The percentage of total catechins obtained in this study ranged from $4.13 \%$ to $25.53 \%$. The highest percentage of total catechins was obtained from the treatment of acetone with maceration of 6 hours, $25.53 \%$, followed by an ethyl acetate solvent with a 6-hour maceration time of $23.68 \%$. While the lowest catechin compounds were found in the treatment of water solvents at a temperature of $80^{\circ} \mathrm{C}$ with different maceration periods (6.12, and 18 hours), respectively: $5.60 \%, 4.17 \%$, and $4.13 \%$. 
In this study, it was found that the high yield did not reflect the high catechin value, this was because when extracted with polar or semi-polar solvents, other phytochemical compounds that matched the solvent also dissolved, causing a high total yield. According to (Achyadi et al., 2018), the size of the yield cannot indicate the quality of the product, because the yield is of small value does not necessarily have a low-quality product, and vice versa, the yield of a large value is not necessarily the product has a low quality value. According to Vuong et al. (2010), the catechin extract obtained contained other components besides the catechins which were dissolved in the solvent as well as the residual solvent remaining, thereby affecting the high yield.

Types of solvents different in this study showed significant differences in the total catechin content of betel nut peel extract. The levels of catechins obtained from acetone solvents $(19.87 \%)$ were not significantly different from those of ethyl acetate $(19.75 \%)$ higher than those of catechins with water solvents at $80^{\circ} \mathrm{C}(4.90 \%)$. This is because acetone is an extraction solution that matches its polarity with the extracted compound, the areca nut peel catechin. This is supported by Sangthong et al. (2013) reported that acetone is the best solvent for extracting catechin compounds from areca seed. The choice of the type of solvent must consider the suitability of the solvent with the solute (polarity), toxicity, volatility, availability, and price of the solvent. Acetone is a polar solvent, liquid, colorless, food-grade (harmless if used as a solvent for food analysis) and flammable (Tiwari et al., 2011).

In this study the longer the maceration time $(6,12$ and 18 hours) the reduced levels of EKKBP catechins obtained for all types of solvents. The highest catechin levels were obtained at 6 hours maceration time (18.27\%), then prolongation of maceration time to 12 hours, catechin levels were reduced at $12.91 \%$ and at 18 hours the catechin content level was $13.49 \%$. The ability of a solvent to dissolve a compound is also influenced by the length of time of maceration. According to Maulida \& Naufal (2014), the longer the extraction process, the longer the contact between the solvent and the solute, so that the solute dissolution process will continue until the solvent is saturated with the solute. However, in this study, an extended period of maceration showed lower levels of total catechins. According to Sintha (2008), the extraction time on each material has an optimum limit, the addition of time beyond its optimum limit has no effect because the compound that has moved to the solvent will experience a saturation point and has been extracted optimally.

\section{CONCLUSION}

It concluded the combination of distillate acetone solvent and maceration duration for 6 hours was the best combination to obtain catechin extract from Areca catechu peel. In this condition the percentage of water content was $10.53 \%$, yield percentage was $7.13 \%$, and percentage of catechin extract was $25.53 \%$.

\section{ACKNOWLEDGMENTS}

This study was funded through "SKIM PENELITIAN DASAR" by Indonesian Ministry of Education and Culture, with contrac number: 163/SP2H/LTDRPM/2019. We appreciate to Indonesian Ministry of Education and Culture who provided us the opportunity and financial support to perform this research. We also thank to the Research Institutions and Community Service of Andalas University, which facilitated this research.

\section{REFERENCES}

[1] Achyadi, N.S., A.D. Sutrisno, A. Fauziah. 2018. Pengaruhbahanpengekstrakterhadapkarakteristikekstraksenyaw afungsionaldarikulitbuahnagamerah (Hylocereuspolyrhizus). Pasundan Food Technology Journal, Volume IV, No.1.

[2] BabuP.V.A., and D. Liu. 2008. Green tea catechins and cardiovascular health: an update. Current Medicinal Chemistry.15 (18).1840-1850.

[3] BadanPusatStatistik . 2017. StatistikProduksiKehutanan. ISSN : 2580-1740. NomorPublikasi : 05320.1807. Katalog : 5601005.

[4] Burdick and Jackson. 2012. Polarity index a relative measure of the degree of interaction of the solvent with various polar test solutes. Diakses 21 Agustus 2019 dari https://www.slideshare.net/datlan2002/polarityindex?from action=save

[5] Cheong, Won Jo, Park, Moon Hee, Kang, Gyoung Won, Ko, Joung Ho, \& Seo, You Jin. 2005. Determination of catechin compounds in korean green tea infusions under various extraction conditions by high performance liquid chromatography. Bulletin Korean ChemmicalSociety. Vol. 26, No. 526. 747-754.

[6] Damanik, D. D., Surbakti, N., \& Hasibuan, R. 2014. Ekstraksi Katekin Dari Daun Gambir (Uncaria Gambir Roxb) Dengan Metode Maserasi. JurnalTeknik Kimia USU, Vol. 3, No. 2. 1014.

[7] DepartemenKesehatanRepublik Indonesia.2008. Farmakope Herbal Indonesia.DepartemenKesehatanRepublik Indonesia. Jakarta.

[8] Druzynska, B., Stepniewska, A., \& Wolosiak, R. 2007. The influence of time and type of solvent on efficiency of the extraction of polyphenols from green tea and antioxidant properties obtained extracts. ACTA Scientiarum Polonorum. Vol 6(1), 27-36.

[9] Evans, W.C. 2002. Pharmacognosy 15th edition. W.B. Saunders. London.

[10] Firdiyani F., T.W. Agustini, W.F. Ma'ruf. 2015. EkstraksisenyawabioaktifsebagaiantioksidanalamiSpirulinaplat 
ensissegardenganpelarut yang berbeda. JurnalPengolahanHasilPertanian Indonesia. Vol. 18 (1), 28-37.

[11] Gruenwald, J., Brendler, T., \& Jaenicke, C. 2000. PDR for Herbal Medicines. Medical Economics Company. Montvale. ISBN: 1-56363-361-2.

[12] Hidayatullah, M. E. 2008. Senyawa Metabolit Sekunder (Catechin).Program StudiBiosainFakultasPascaSarjana. Universitas Negeri Sebelas Maret. Solo.

[13] Ikeda, I. 2008. Multifunctional effects of green tea catechins on prevention of the metabolic syndrome. Asia Pacific Journal of Clinical Nutrition. Vol. 17, 273-274.

[14] Kamaluddin, M.H., M. Lutfi, Y. Hendrawan. 2014. Analisapengaruh microwave assisted extraction (mae) terhadapekstraksisenyawaantioksidancatechinpadadauntehhija $\mathrm{u} \quad$ (Camellia sinensis) (kajianwaktuekstraksidanrasiobahan:pelarut). Jurnal Keteknikan Pertanian Tropisdan Biosistem Vol. 2 No. 2.147155.

[15] Kristian, J., S. Zain, S. Nurjanah, A. Widyasanti, S. HarnesaPutri. 2016. Pengaruh lama ekstraksiterhadaprendemendanmutuminyakbungamelatiputihm enggunakanmetodeekstraksipelarutmenguap (solvent extraction). Jurnal Teknotan Vol. 10 No. 2, 34-43.

[16] Mahata, M. E., Yose, R., \& Ardi. 2018. Pengolahan limbah kulit buah pinang (Areca catechu 1.) dengan mikroorganisme lokal (MOL) sebagai pakan aditif ternak unggas. Universitas Andalas, Padang.

[17] Mamonto, S. I., Runtuwene, M. R., \& Wehantouw, F. 2014. Aktivitas antioksidan ekstrak kulit biji buah pinang yaki (Areca vestiaria giseke) yang di ekstraksi secara soklet.PHARMACON JurnalIlmiah Farmasi. Vol.3(3), 23022493.

[18] Maulida, D., dan N. Zulkarnaen. 2010. Ekstraksiantioksidan (likopen) dari buah tomat dengan engg unakansolvencampuran, n-heksana, asetondanetan ol. UniversitasDiponegoro. Semarang.

[19] Muliani, H. 2015. Effect of turmeric (Curcuma domesticaVahl.) extract on broiler blood cholesterol levels. Jurnal Sainsdan Matematika. Vol. 23 (4), 107-111.

[20] Ozdemir, F., S. Nadeem, A. Akdogan, C. Dincer, A. Topuz. 2018. Effectof altitude, shooting period, and tea grade on the catechins, caffeine, theaflavin, and thearubiginof turkish black tea. Turkish Journal of Agriculture and Forestry.42: 334-340.

[21] Park, Y. B., Jeon, S. M., Byun, S. J., Kim, H. S., \& Choi, M. S. 2002. Absorption of intestinal free cholesterol is lowered by supplementation of Areca catechu L. extract in rats. Vol. 70, 1849-1859.

[22] Prasetyo, M. S., danInoriah, E., 2013, Pengelolaan Budidaya Tanaman Obat-Obatan (Bahan Simplisia).Fakultas Pertanian UNIB, Bengkulu. ISBN: 978-602-9071-10-8.

[23] Raederstorff, D.G., M. F. Schlachter, V. Elste, P. Weber. 2003. Effect of EGCG on lipid absorption and plasma lipid levels in rats. Journal of Nutritional Biochemistry. Vol. 14, 326-332.

[24] Ratnani, R.D. I. Hartati, Y. Anas, D. Endah, dan D. Khilyati. 2015. Standarisasi Spesifik Dan non spesifikekstraksihidrotropiandrographoliddarisambiloto (Andrographispaniculata). Prosiding Seminar Nasional Peluang Herbal Sebagai Alternatif Medicine. ISBN: 978-60219556-2-8.

[25] Sangthong, S., P. Pintathong and P. Chaiwut. 2013. Microwave-assisted solid-liquid extraction of biological compoundsfrom Areca catechu L. seed. BuraphaScience Journal.Vol. 18 No.2 : 195-202.

[26] Satriadi, T. 2011. Kadar tanin biji pinang (Areca Catechu L.) dari Pleihari. Jurnal Hutan Tropis. Vol.12(32), 132-135.

[27] Sayuti, M. 2017. Pengaruhperbedaanmetodeekstraksi, bagiandanjenispelarutterhadaprendemendanaktifitasantioksida nbambulaut (Isis hippuris). Technology Science and Engineering Journal, Volume 1 No 3, 166-174.

[28] Sintha, Endrodan A. Puspitasari. 2008. Pengaruhkonsentrasialkoholdanwaktuekstraksiterhadapekstrak si tannin dannatriumbisulfitdarikulitbuahmanggis. Makalah Seminar Nasional Soebardjo Brotohardjono. ISSN 1978-04

[29] Susanti, E., Rudijanto, A., and Ratnawati, R. 2012. Catechins inhibit atherosclerosis in male rats on a high fat diet. Universa Medicina. Volume 31(2), 81-87.

[30] Tiwari, P., Jain, R.. Kumar, K. Panik, and Sahu. 2011. An evaluation of antimicrobial of root extrac of (Calendula officinalis L.). Pharmacologyonline. Volume 2, 886-892.

[31] Utami, Y.P., A.H. Umar, R. Syahruni, I. Kadullah. 2017. Standardisasisimplisiadanekstraketanoldaunleilem (Clerodendrumminahassae Teisjm. \&Binn.). Journal of Pharmaceutical and Medicinal Sciences 2 (1): 32-39.

[32] Uzunalic, A. P., Skerget, M., Kez, Z., Weinreich, B., Otto, F., \& Gruner, S. 2006. Extraction of active ingredients from green tea (Camellia sinensis): extraction effeciency of major catechins and caffeine. Food Chemistry. Volume 96, 597-605.

[33] Vuong, Q.V., J.B. Golding, M. Nguyen, P.D. Roach. 2010. Extraction and isolation of catechins from tea. Journal of Separation Science. Volume 33 (21), 3415-3428.

[34] Yeni, G., K. Syamsu, E. Mardliyati, dan H. Muchtar. 2017. Penentuanteknologi proses pembuatangambirmurnidankatekinterstandardarigambirasalan. JurnalLitbangIndustri. Volume 7 (1), 1-10.

[35] Yudha, A.P.2017. Peluang Ekspor Gambir dan Biji Pinang. Warta Ekspor. Jakarta. Ditjen PEN/MJL/32/V/2017.

[36] Yunarto, N., Elya, B., \& Konadi, L. 2015. Potensi fraksi etil asetat ekstrak daun gambir (Uncaria gambir Roxb.) sebagai antihiperlipidemia. Jurnal Kefarmasian Indonesia. Volume 5(1), 1-10.

[37] Yunarto, N., I. Sulistyowati, A. A. Kurniatri1, dan N. Aini. 2017. Pengaruh penyalut anter had apkarak teristik fisikak imiadan stabilitas tablet fraksi etil asetat daungam birse bagaiagenanti dislipidemia. Media Litbangkes.Vol. 27 No. 2 :71-78.

[38] Zulharmita, U. Kasypiah, H. Rivai. 2012. Pembuatan dankarakteri sasiek strak kering daunjam bubiji (Psidiumguajava L.). Jurnal Farmasi Higea, Volume 4 (2), $147-157$ 